\title{
E-Governance "Innovation for Citizen Centric Governance" Through the Development of SMS Gateway System to Online Registration
}

\author{
Joko Tri Nugraha ${ }^{1}$, Tarmizi Achmad ${ }^{2}$,Hardi Warsono ${ }^{3}$, Tri Yuniningsih ${ }^{4}$ \\ \{jokotrinugraha@untidar.ac.id ${ }^{1}$, t.achmad18@gmail.com² ${ }^{2}$,hardie_wsn@ live.undip.ac.id ${ }^{3}$, \\ triyuniningsih@yahoo.com ${ }^{4}$ \} \\ Faculty of Social and Political Sciences, Tidar University, Magelang, Indonesia ${ }^{1}$ \\ Faculty of Economics and Business, Diponegoro University, Semarang, Indonesia ${ }^{2}$ \\ Faculty of Social and Political Sciences, Diponegoro University, Semarang, Indonesia ${ }^{3}$
}

\begin{abstract}
In practice e-governance includes the interactions of G2G, G2B, G2E and G2C. This paper describes the interaction of G2C through the development of the SMS gateway system to the online registration at Margono Soekarjo Hospital, Purwokerto Central Java. Margono Soekarjo Hospital is a hospital belonging to the government of Central Java, referencing class B education is located in Purwokerto with the reach of the Central Java region of South West, so it needs an informative system and support for the acceleration of the registration service. The problem faced is the length of waiting for the registration service, not sure when the registration service, the comfort of the waiting room, high complaints of registration services and low patient satisfaction to the registration service. The method used is a qualitative descriptive by using researchers as a tool based on literature studies. The results of the study showed this system was user friendly so can be used by all walks of life.
\end{abstract}

Keywords: citizen centric, e-governance, information technology.

\section{Introduction}

Initiatives e-government have come a long way in the last decade. This is because many parties are aware of the advantages of government services using electronic media, which are more effective and efficient [1]. One of the efforts to realize good governance is to accelerate work processes and modernization of administration through automation in the field of office administration, modernization of service delivery to the public through e-government as one of the applications of information technology. Several services such as taxation, residence identity card, driver's license, passport, application online to support government work using information technology. Government services that are traditional in nature have been transformed using information technology in recent years [2], [3]. The main problem faced in the implementation of regional autonomy is the limited means and infrastructure for communication and information to disseminate various central and regional government policies to the community, so that the process of government administration, development 
management and community empowerment can be more effective, efficient, transparent and accountable [4].

Therefore, in the implementation of governance towards good governance and in order to accelerate the implementation of regional autonomy, the development and implementation of egovernment is a strategic alternative in order to communicate information in two directions between the government and the community and the business world and between the governments themselves [4]. The new service concept that adopts this industrial sector is considered to be better and faster in the service process, cheaper in communicating service products to the public which is called the technological revolution [5].

As a field of science and research discipline, digital government has reached the world. In the global arena, researchers have made major discoveries in international research. Recently several researchers [6] reviewed the results of international studies in the field of digital government very little before 2001. Then it developed from 2005 to develop into 65 studies and started to decline again from 2006-2008. Although some of the results of these studies reinforce the importance of e-government, efforts to carry out international studies are still very rare and some in the world overlap in collaborating with governments to solve public problems that have become a habit [6]. The results of these studies are highly relevant in Europe, but very little of the same effort has been found in North America [6], [7].

The terms "digital government" and "e-government" have appeared more than 15 years ago to mean the use of information and communication technology in the government sector, and this definition has always evolved over time [8], [9], [10]. The conceptualizations of electronic government are very diverse [11], [12], [13], [14]. The narrow viewpoint defines e-government only as the use of the internet to provide public services, while a broader view defines it as the use of information and communication technology in government.

Digital government can be defined as the use of information and communication technology by state agencies and citizens. This provision is included in the service process and management process in the legislature, where technology can strengthen citizens to gain greater access to services and more effective and flexible participation in the process of government participation and strengthening interactions between citizens and government [15]. E-government is a worldwide phenomenon to improve service delivery and internal efficiency of government organizations [16]. E-government is defined as a way for governments to use the most innovative information and communication technologies, particularly-based internet applications web, to provide citizens and businesses with easier access to government information and services and to provide opportunities to participate in democratic process situations [17].

The rapid development of information technology, which is accelerated by the presence of the internet, has encouraged various areas of life to make optimal use of this technology. The use of the internet in governmental aspects encourages the realization of e-government in society through increasing access to information, improving government services to its citizens, strengthening interactions between businesses and government in related industries, improving government management that is more efficient and transparent [18]. New technologies can be used by developing countries to create structures e-government that benefit citizens and their national development processes [19]. Information and Communication Technologies (ICTs) create possibilities and benefits for governments in the world. ICTs are used to improve service quality, to reduce costs, and to make policies and programs more effective [8], [20], [21]. Information and communication technology are also used as a catalyst for organizational change [22], [23]. ICTs are also used as tools to increase democratic participation in politics and public 
organizations [24], [25]. There is no innovation without the application of IT in the bureaucracy, or there can be no good service without e-government [26].

The rapid development of information and communication technology (ICT) has also penetrated various sectors including the government sector. The application of ICT in public sector organizations in developing countries is used as a very important tool to bring about improvements in local governance [27]. Information and communication technology have revolutionized the relationship and interaction between citizens and government, and this innovation has brought about a new form of government called e-government [28]. In Indonesia, the use of ICT by government agencies (e-government) began to roll under a policy, namely Presidential Instruction No. 3 issued in 2003 regarding national policies and strategies for development e-government. Furthermore, it was updated by Presidential Regulation Number 95 of 2018 concerning electronic-based government systems.

However, the realization of e-government in Indonesia faces many challenges in terms of geography, economy, technology and culture [4]. Currently, the issue of e-government is increasingly being raised among the government and business people in Indonesia, especially in relation to improving government services to the community, strengthening the interaction of business people in related industries through increasing access to information, to noble goals such as governance management. efficient. E-governance is a driving force to create good governance in which the SMART concept is defined as a simple, moral, accountable, responsive, and transparent government [29], [30]. Therefore, in the implementation of government towards good governance and in order to accelerate the implementation of regional autonomy, the development and implementation of e-government in various forms including G2G, G2B, G2E and G2C are strategic alternatives in order to communicate information in two directions between the government and society and the business world and the government itself [31], [32], [33], [34], [35].

One form of G2C relationship is the development of an SMS gateway to registration online (penetration online) which has been carried out by Prof. Dr. Margono Soekarjo county general hospital. The main problem at that time was the long waiting time for registration (2 hours); uncertain time of registration service; the uncomfortable waiting room which includes the physical condition and safety of visitors; high complaints of registration services (based on 2015 public complaint data before the innovation) and; Low patient satisfaction with registration services was 61.65 percent based on the 2015 IKM survey data, prior to innovation (2018 RSMS Annual Report).

Monitoring and evaluation of services through the SMS gateway was conducted from June to August. From the results of the evaluation, there were several inputs from the patient to improve the system, including so that the patient could choose a check-up date seven days before the day of service needed and could choose a guarantor. While input from care workers, among others so that the patient can perform entry data privately so when signing-care workers do not need to perform entry data back, so that the registration process will be faster. To meet this need, the service using an SMS gateway was then developed into a registration system online.

In more detail, the problems faced before the G2C innovation initiative were penetration online at Prof. Dr. Margono Soekarjo county general hospital is as follows: First, the length of waiting time for registration. As many as 80 percent of patients arrive early, around $05.00 \mathrm{WIB}$ with the hope of getting the queue number as early as possible, while the registration counter opens at 07.00 WIB. The peak of the visit occurred at 10.00 WIB. With an average of each counter serving 75 patients per day, registration of one patient takes 5 minutes, so serving patients takes 6 hours exceeding the supposed counter opening hours (RSMS Annual Report 2018). 
Second, there is uncertainty in the registration service time. When taking the queue number, you only get the queue number but there is no information when it will be served so the patient waits until the queue number is called. Third, the waiting room is uncomfortable, which includes the physical conditions and safety of hospital visitors. The accumulation of visitors and patients in the outpatient registration waiting room resulted in uncomfortable waiting room conditions (the waiting room was hot, stifling, didn't get a chair, the bathroom was queuing up, the risk of getting nosocomial infections or getting sick in the hospital was very high).

Fourth, the high number of complaints about registration services, amounting to 11.6 percent based on the 2015 public complaint data before the penetration innovation was carried out online. Complaints in 2015 (before innovation) through the suggestion box totaled 43 complaints and 11 respondents (25.6 percent) complained about registration services, disorderly queues, unfriendly officers and long service waiting times (Data on public complaints reports 2015). Fifth, the low level of patient satisfaction with registration services is 61.65 percent (IKM survey data for 2015 before innovation).

Based on this problem, this G2C interaction innovation was developed for all insurers (General, BPJS, JAMKESDA, BUMN, LPSK and other insurers). This system is user friendly so that it can be used for all levels of society with the results of efficiency of registration waiting time from 2 hours to 15 minutes, there is certainty of registration service time, the waiting room is comfortable both in physical condition and safety of patients or visitors, customer complaints have decreased from 25,6 percent to 2.4 percent and community satisfaction increased from 61.65 percent to 82.13 percent. This G2C innovation has made it into the National Top 99.

The hospital is a condition entity with a service feel. Therefore, the paradigm of organizing an organization, although it has a mission to maintain public health, is also a profit-oriented regional company. The work mechanism should not only make it easier for employees to work, but must also have a patient-oriented perspective. This article discusses the innovation process carried out by Margono Soekarjo county general hospital, as well as the challenges and obstacles encountered in providing medical services to the community.

\section{Methodology}

The method used in discussing this article is a qualitative descriptive method using researchers as a tool based on literature study. According to [36] in the literature study, researchers are tasked with exploring the theories that have developed in the field of science concerned, looking for research methods and techniques both in collecting data and analyzing data that have been done by previous researchers, obtaining a broader orientation in selected problems and avoiding unwanted duplications. Writing this article uses the literature study method, in addition to seeking from secondary data that will support research, it is also necessary to find out to what extent the science related to research has developed, to what extent there are conclusions and generalizations that have been made, so that the necessary situation can be obtained.

To gather information that is relevant to the topic or problem to be discussed in this paper, the author uses a literature study. Namely, data collection techniques by conducting study studies of books, literature, notes, and reports that have to do with the problem being solved [37]. Efforts to collect this information can be obtained from scientific books, research reports, scientific essays, theses and dissertations, regulations, statutes, yearbooks, encyclopedias and other written and electronic sources. Furthermore, in order to obtain clear characteristics of the 
discourse in the form of the studied theories and concepts, the author uses the method content analysis, which is a research technique to make inferences that can be replicated (imitated) and validate the data by paying attention to the context [38], [39].

\section{Finding and Discussion}

\subsection{Problem Analysis}

E-government plays a potential role for citizens and government as a unit. With egovernment there will be increased capacity to improve and develop government services through information technology that can be accessed at any time. The potential effect of implementing e-government is to enrich existing theories with various variations and the surrounding contexts. With technology like this makes the government more efficient and transparent to the public [14], [40], [41].

E-government will make the government more responsive in providing services to the public through technology choice options that are faster and more convenient for its users [42]. E-government will also increase transparency towards the people it serves and make government units more accountable to the communities they serve [43].

The presence of-based systems online will also reduce government agency costs, remove barriers between service products and information access, and make service updates faster online than using traditional service methods [44]. In addition, [45], [46] argued that information technology has a significant relationship in the supervision of power, responsibility, and control between government agencies and between the public and private sectors.

RSUD Prof. Dr. Margono Soekarjo is a Class B Education referral hospital in Central Java Province located in Purwokerto. The coverage of the southern western part of Central Java with the closest distance of other referral hospitals is $216 \mathrm{~km}$, this condition makes the number of outpatient visits per year averaging 599 patients per day (RSMS annual report, 2018).

Table 1. Comparison of Conditions Before and After the Innovation.

\begin{tabular}{|c|c|c|c|}
\hline No & Indicators & Before Innovation & After Innovation \\
\hline 1 & Number of visits per day & 670 & 780 \\
\hline 2 & $\begin{array}{l}\text { Number of queues per } \\
\text { counter }\end{array}$ & 83 & 97 \\
\hline 3 & Queue waiting time Queuing & $\begin{array}{l}\text { machine starts functioning at } \\
05.00 \text { and first queue number } 1 \\
\text { is served at } 07.00 \text { so queue } \\
\text { number } 1 \text { waits } \pm 2 \text { hours } \\
\text { before being served, time } \\
\text { Patient service averages } \pm 5 \\
\text { minutes }\end{array}$ & $\begin{array}{l}\text { Patients have received a queue } \\
\text { number with the online } \\
\text { registration system and have } \\
\text { been informed about the } \\
\text { estimated time of service so that } \\
\text { patients only need to wait a } \\
\text { maximum of } 15 \text { minutes with a } \\
\text { registration service time of } 2.5 \\
\text { minutes. }\end{array}$ \\
\hline
\end{tabular}

Source: Primary Data Processed, 2020

\subsection{Strategic Approach}

Who has proposed a solution and how has this public service innovation solved the problem at hand? 
a. Patients, submit directly to the officer and complaint room with suggestions or input to add registration counters, waiting chairs and air conditioners.

b. Customers or visitors, convey through customer meetings that are held 2 times a year, suggestion boxes located at registration counters and outpatient clinics, SMS sent to the director, complaint room, twitter and email, among others suggesting that queues take place via SMS and queues per clinic.

c. Stakeholders, conveying at the DPRD Commission session of Central Java Province, suggested using information technology such as railroad companies.

d. Hospital management, problems and suggestions or input from various parties are discussed through a Focus Group Discussion (FGD) forum between fields or sections formed to accommodate innovative ideas to become more systemic and institutionalized. The results of the FGD agreed that there was a need for a facility or system that could resolve complaints about long queues and a long registration process, with the following steps:

1. Designing or designing a registration service system that is easy, cheap and fast.

2. Designing registration services with information technology that is simple and accessible.

3. Implementing SMS Gateway.

4. Developed SMS Gateway into Registration Online.

With the innovation of the G2C system called Penetration Online, it is hoped that it will accelerate the waiting time for registration services which in turn increases customer satisfaction. Registrants no longer need to queue and even scramble to get the smallest queue number.

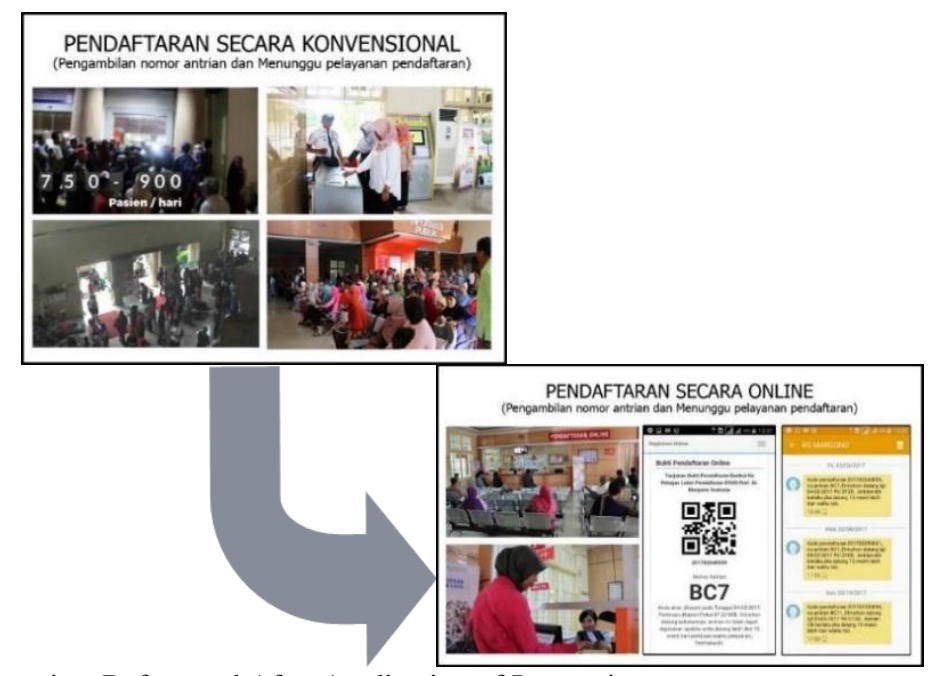

Fig. 1. Overview Before and After Application of Innovation

Penetration Online (Development of the SMS System for Gateway Registration Online) which is implemented at the Outpatient Registration Counter is creative and innovative because: a. More informative

Provides information on the time of outpatient registration services, so that registrants come at that time and are sufficient to wait a maximum of 15 minutes. 
b. It is safer with the use of a barcode.

Registrants only need to show the barcode on the screen cell phone when registering so as to speed up registration time and avoid data registration verification errors.

c. More flexible (free to choose the check date and time of registration)

Applicants can choose one to seven days before the inspection date according to their needs and do not have to come in person to take the queue, but can collect it through the online system anytime, anywhere, and in any condition so that it is more efficient in cost, time and effort.

d. User Friendly

System can be used for all insurers (General, BPJS, Jamkesda, BUMN, LPSK and other insurance). This shows that this system is user friendly so that it can be used by all levels of society.

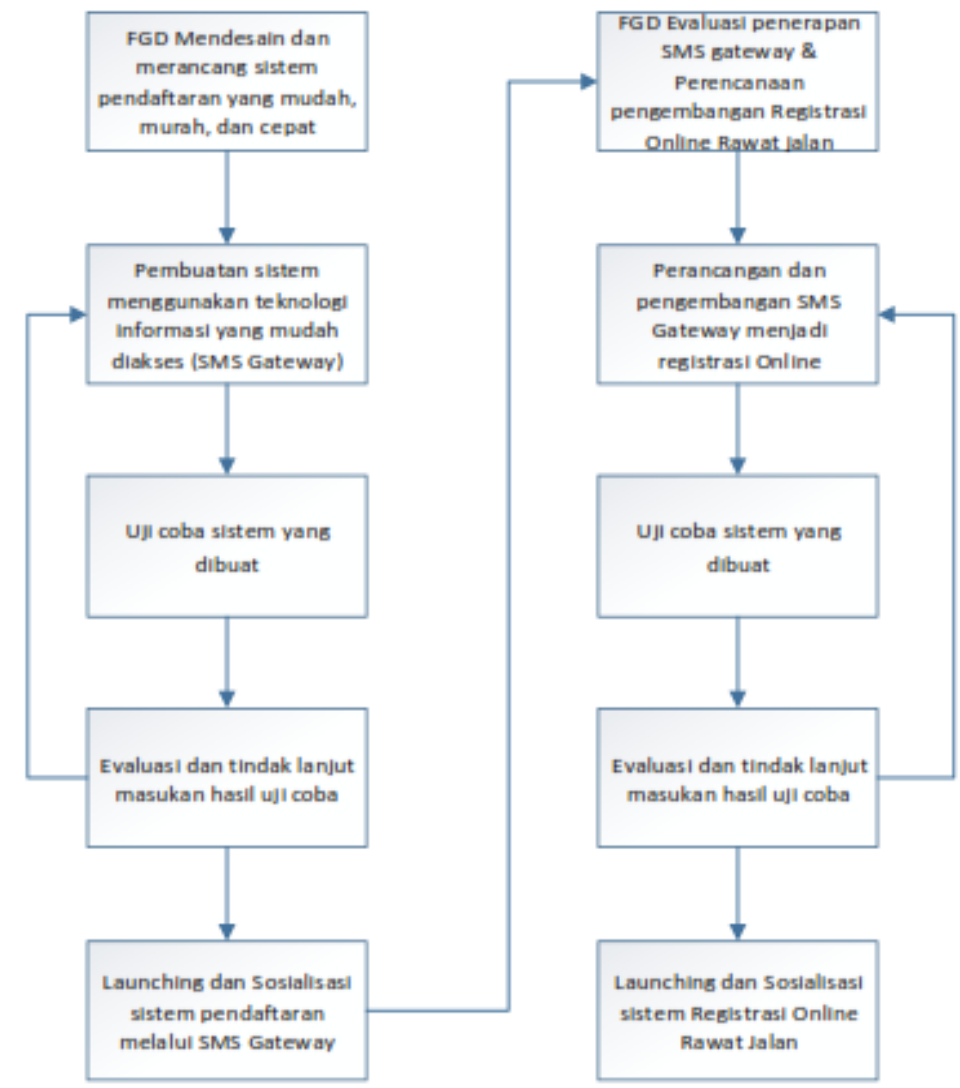

Fig. 2. Penetration Innovation Implementation Process Online

The steps for taking a strategic approach to $\mathrm{G} 2 \mathrm{C}$ interaction through penetration innovation online are as follows:

a. Conducting a Focus Group Discussion (FGD) to design or design a registration service system that is easy, cheap and fast. 
In January 2016, a field and division meeting were held to formulate, plan and design a system to support easy, cheap and fast registration services. From several meetings it was decided to create a registration system using the SMS Gateway.

b. Creating a service design with information technology that is simple and easily accessible.

In February 2016 a meeting was held to design an SMS system Gateway with the IT team of Prof. Dr. Margono Soekarjo. In March 2016, the initial design of the SMS Gateway was presented in FGDs in the fields and sections and several improvements were made to the system. In April 2016 the system was tested internally. Feedback from the trial became material for further improvements, then socialization and carried out soft launching of the SMS service was Gateway in May 2016. In June 2016 launched the SMS service was Gateway.

c. Evaluation of SMS services Gateway.

Monitoring and evaluation of SMS services Gateway from June to August 2016. From the results of the evaluation, there were several recommendations from patients for improving the system, including so that patients can choose a check-up date 7 days before the required service day and can choose a guarantor. While input from officers, among others, so that the patient can perform entry data privately so when signing, the officer did not have to perform re-entry of patient data, so the registration process faster. To fulfill this need, it was decided to develop the SMS Gateway into registration online.

d. Developing the SMS Gateway system to become a Registration System Online.

In September 2016 a meeting was held with the IT team to design a registration system online. In October 2016 the IT team presented the initial design of the registration system online in FGD fields and departments. Various inputs from the FGD results became materials for the refinement of the initial design of the registration system online. In October 2016, there was a trial and socialization of the registration system online to internal parties. In early December 2016, carried out soft launching of outpatient registration services was through an online registration system. The 1st and 2nd week of December, carried out monitoring and evaluation of the application of the registration system was online and on December 27, 2016 the registration system was online officially launched through various media.

Some of the parties involved in the realization of the implementation of penetration online include:

a. Outpatients, which include patients with BPJS guarantor, General, BUMN and other health insurance.

b. Areas and sections that formulate and decide policies, flows and system regulations.

c. Medical record staff, supervisor staff, public relations staff who provide socialization and assistance to patients in using the SMS system gateway and registration online.

The next development, in 2020 RSMS already has an android and web-based application that includes Online Registration (based on individual guarantor), Tele neat and TT dik Depe (Empty bed connected to Discharge planning) which are all innovations to simplify and accelerate services with achievements. application utilization of $90 \%$ of service users. On the other hand, BPJS has the Mobile JKN application as an application that contains service information and queues based on health facilities with the same goal of simplifying and accelerating services. 
From the description of outpatient services at RSMS, an average of 750-1100 per day with a proportion of $90 \%$ of patients with BPJS insurance need a system that speeds up and makes it easier for BPJS participants to access hospital services. Service certainty is very important for BPJS participants who get service at FKTP and need to be referred to Margono Soekarjo Hospital, Purwokerto. A queuing system based on health facilities needs to be built with the objectives of: (1) Increasing access to hospital services (coverage and coverage) and; (2) Increase service certainty (patients have received information on registration queues and clinics 7 days to 1 day before service) on mobile JKN and RSMS Online.

The Meaning of Integration of Hospital Information Systems and BPJS in 2020 was launched as a National Pilot Project. Margono Hospital which already has the RSMS Online application and BPJS has Mobile JKN are integrated to simplify and speed up services. BPJS participants can take advantage of the health facility-based queuing service model. Coupled with the display of bed occupancy, information is still very much needed by BPJS participants as a form of openness of hospital services. Empty bed displays based on class can be accessed by the public via RSMS Online and Mobile JKN in real time. This shows the commitment of RSMS and BPJS to provide the best for the community.

\subsection{Resources Used}

Resource requirements needed in this activity include:

a. Human Resources

IT team Prof. Dr. Margono Soekarjo, who has the ability in information technology so that he can design, build, use and maintain the system optimally.

b. Source of Funds.

Source of funds for implementing this innovation comes from BLUD RSUD Prof. Dr. Margono Soekarjo Purwokerto, Central Java Province for purchasing barcode readers 2D, queuing LCDs, printing leaflets, banners, booklets and press releases.

c. Server and Network Devices Internet

Servers and internet networks that have been owned by Prof. Dr. Margono Soekarjo Purwokerto, Central Java Province, was optimized for the implementation of the registration system online at Prof. Dr. Margono Soekarjo Purwokerto

d. Regulation

Policy Director of RSUD Prof. Dr. Margono Soekarjo Purwokerto number 445 / 14970a / VI / 2016 concerning Registration Policy Online at Prof. Dr. Margono Soekarjo Purwokerto is the basis and guideline for implementing penetration online.

The Output resulting with penetration online is:

a. Reduced waiting time at registration counters.

The efficiency of registration waiting time is 1 hour 45 minutes, from 2 hours to 15 minutes.

b. There is a certain time for the registration service.

The registration service time of each registrant is informed via SMS or Email, so that there is certainty and the registrant can plan his arrival.

c. The waiting room becomes comfortable both in physical condition and safety of patients or visitors.

After the implementation of penetration online the waiting room became more comfortable because there were not too many registrant waiting in line.

d. Customer complaints decreased. 
Customer complaints through the suggestion box before innovation 25.6 percent complained about registration services, disorderly queues, unfriendly officers and long waiting times. After the application of penetration online fell to 2.4 percent, namely 1 complaint about registration services from 41 complaints that were submitted (Public Complaints Report, 2018).

e. Community satisfaction increases.

Faster waiting times and a more comfortable waiting room make registrants more satisfied with registration services, previously the level of satisfaction with services was registration 61.65 percent after the application of penetration online increased to 82.13 percent (IKM, 2018).

Some of the obstacles faced in implementing penetration online this include:

a. Not all users of the registration system online have a device to access the system.

Efforts made to overcome the above obstacles are designing a registration system online not only for those concerned. Facilities for registering others have been provided and can print proof of registration (barcode registration code online).

b. Not all users of the registration system online have internet quota.

Efforts are Prof. Dr. Margono Soekarjo hospital provides facilities free internet access in various service environments.

c. Not all users understand the flow and how to use registration online.

Efforts made are assistance by special officers who educate the public about registration online, socialization and providing leaflets / banners on how to use the registration system online as well as desk a public information service located in the registration area.

\subsection{Main Impacts of G2C Interaction on Penetration Service Innovations Online}

impacts obtained before and after the penetration innovation online are:

1. Faster waiting times.

Previously, the waiting time 2-3 hours after the implementation of the waiting time system became 15 minutes from the estimated service time that was informed. For a concrete example, before registering, Mr Slamet will take a queue where the queue machine opens at $05.00 \mathrm{WIB}$, he must take the queue as soon as possible to get the smallest queue number while the new registration counter service opens at $07.00 \mathrm{WIB}$ from this condition it can be concluded that it requires at least 2 waiting times hour. After the application online, registration can be done 1 to 7 days before the date of the examination and can find out when the service time is so that it is enough to come at that time and simply wait a maximum of 15 minutes.

2. Ease of registration, this includes:

a. Can make outpatient service reservations a week in advance.

Previously, registration could only be done on the day after the registration system was used 7 days before the examination was carried out. Before the application of registration online, patients must come to collect the queue number according to the date the patient will perform the examination. After application the patient can register 1 to 7 days before the date of examination.

b. There is certainty of service time.

Previously, customers did not get information when their registration would be served. After using the system, customers received information on when the outpatient registration service was. A concrete example of Mr Slamet after getting 
queue number 10 at $05.00 \mathrm{WIB}$ and waiting to be served without knowing the certainty when it will be served at the registration counter. After the application of the registration system online, patients at the time of getting queued also get certainty of the time when they will be served at the registration counter, for example, the BC11 queue will be served at $07.30 \mathrm{WIB}$.

c. User Friendly.

The system can be used to register all guarantors (GENERAL, BPJS, JAMKESDA, BUMN, LPSK and other insurance). This shows that this system is user friendly so that it can be used by all levels of society.

3. Waiting room comfort (physical condition and safety of visitors).

After the implementation of penetration online, the arrival of the customer is in accordance with the estimated service time that has been informed, so that it does not come simultaneously. This has an impact on the comfort of the waiting room which is not too full. Previously, the registration waiting room was always crowded with patients and patient companions who would register and were at risk for nosocomial infections.

4. Information transparency.

Information related to services, especially information on outpatient registration services, is more transparent (queues, requirements, service time, clinic opening days), so that collusion and nepotism are avoided.

Tabel 2. Conditions Before and After Application of the Innovation.

\begin{tabular}{|c|l|l|}
\hline No & \multicolumn{1}{|c|}{ Sebelum Inovasi } & \multicolumn{1}{|c|}{ Sesudah Inovasi } \\
\hline 1 & Before Innovation & After Innovation \\
\hline 2 & Long waiting time (2-3 hours) & Fast waiting time (15 minutes) \\
\hline 3 & $\begin{array}{l}\text { Must register directly and queue (3 times; queue } \\
\text { to open the waiting room door, queue for } \\
\text { numbers, queue for registration services) }\end{array}$ & $\begin{array}{l}\text { Can make reservations outpatient services one } \\
\text { week before }\end{array}$ \\
\hline 4 & $\begin{array}{l}\text { a. There is no certainty of service time and } \\
\text { queues are less transparentFixed }\end{array}$ & $\begin{array}{l}\text { a. Service time, according to schedule and } \\
\text { transparent queues }\end{array}$ \\
\hline 5 & $\begin{array}{l}\text { Uncomfortable waiting rooms: } \\
\text { a. Crowded visitors, hot, standing visitors, risk } \\
\text { of nosocomial infection. } \\
\text { b. Rampant practices of collusion, nepotism } \\
\text { and brokering. }\end{array}$ & $\begin{array}{l}\text { The lounge area is safe and comfortable: } \\
\text { a regular visitor flow, enough waiting chair, } \\
\text { the risk of nosocomial infection minimal } \\
\text { b. Disappearance of collusion, nepotism and } \\
\text { brokering }\end{array}$ \\
\hline 6 & $\begin{array}{l}\text { Complaint registration services } \\
25.6 \text { percent }\end{array}$ & Complaints registration service 2.4 percent \\
\hline 7 & Value IKM 61.65 percent & Value IKM 82.13 percent \\
\hline
\end{tabular}

Source: Primary Data Processed, 2020 


\section{Conclusion}

Bureaucratic reform is a must in managing public services. Margono Soekarjo Hospital as one of the public service organizations that has the main task of providing public services, especially health services, in its management must ensure that the community receiving services feels comfortable and satisfied. Community satisfaction and comfort must be measured and according to predetermined service standards. The results obtained from the application of the registration system online at Margono Soekarjo Hospital include:

a. The waiting time for medical services has become faster after the innovation.

b. People can make outpatient reservations one week before service.

c. Service times have become more certain and patient queues have become more transparent.

d. The patient waiting room is safer and more comfortable.

e. Complaints on the registration of medical services have decreased.

\section{References}

[1] V. Weerakkody, J. Choudrie, and W. Currie, "Realising e-government in the UK: Local and national challenges," 2004.

[2] R. Heeks and S. Bailur, "Analyzing e-government research: Perspectives, philosophies, theories, methods, and practice," Gov. Inf. Q., vol. 24, no. 2, pp. 243-265, 2007.

[3] B. Mosse and Whitley, "EA Critically classifying: UK e-government Website benchmarking and the recasting of the citizen as a customer," Information Systems Journal, vol. 2, pp. 149-173, 2009.

[4] H. Hardiyansyah, "Kualitas Pelayanan Publik: Konsep, Dimensi, Indikator dan Implementasinya." Gava Media, 2018.

[5] P. Devadoss, S. Pan, and J. Huang, "Structurational analysis of e-government initiatives: A case study of SCO," Decision Support Systems, vol. 34, pp. 253-269, 2002.

[6] ME International digital government research: A reconnaissance study (1994-2008. Albany, NY: Center for Technology in Government, 2009.

[7] C. Navarrete, S. Mellouli, T. A. Pardo, and Gil-Garcia, "JR Information sharing at national borders: Extending the utility of border theory," 2009.

[8] A. V. Anttiroiko and M. Malkia, Eds., "Exploring e-government benefits and success factors," Hershey, PA: Idea Group Inc, 2006.

[9] M. Khosrow-Pour, Ed., "LF Integrating conceptual approaches to e-government," Hershey, PA: Idea Group Reference, 2006, pp. 636-643.

[10] M. Yildiz, "E-government research: Reviewing the literature, limitations, and ways forward," Government Information Quarterly, vol. 24, no. 3, pp. 646-665, 2007.

[11] M. M. Brown and Brudney, "JL Achieving advanced electronic government services: Opposing environmental constraints," Public Performance \& Management Review, vol. 28, no. 1, pp. 96-114, 2004.

[12] K. D. Edmiston, "State and local e-government: Prospects and challenges," The American Review of Public Administration, vol. 33, no. 1, pp. 20-45, 2003.

[13] J. Roy, "The relational dynamics of e-governance: A case study of the city of Ottawa," Public Performance and Management Review, vol. 26, no. 4, pp. 391-403, 2003. 
[14] D. M. West, "E-government and the transformation of service delivery and citizen attitudes," Public administration review, vol. 64, no. 1, pp. 15-27, 2004.

[15] A. K. Elmagarmid and Mciver, "WJ Guest editors' introduction: The ongoing march toward digital government," Computer, vol. 34, no. 2, pp. 32-38, 2001.

[16] R. R. Rao, "E-Governance-A tool for citizen Centric Governance: Implements in Implementation in India," COMPUTING TRENDZ, vol. 6, no. 2, pp. 6-16, 2016.

[17] F. Ibikunle and J. Sarumi, "Electronic-Governance for Nigeria: Opportunities and Challenges in the Digital Era* 1 and," International Journal of Electronic Governance and Research, vol. 1, no. 1, pp. 77-84, 2012.

[18] D. E. Gberevbie, C. K. Ayo, F. O. Iyoha, M. M. Duruji, and U. D. Abasilim, "Electronic governance platform: towards overcoming the challenges of non-inclusion of citizens in public policy formulation and implementation in Nigeria," International Journal Electronic Governance, vol. 10)1, pp. 56-73, 2018.

[19] D. Evans and Yen, "DC 'E-government: evolving relationship of citizens and government, domestic and international development," Government Information Quarterly, vol. 23, no. 2, pp. 207-235, 2006.

[20] J. H. Lim and Tang, "SY Urban e-government initiatives and environmental decision performance in Korea," Journal of Public Administration Research and Theory, vol. 18, no. 1, pp. 109-138, 2008.

[21] J. Roy, "E-government in Canada: Transition or transformation?," D. F. Norris, Ed. Hershey, PA: CyberTech Publishing, 2007, pp. 44-67.

[22] S. S. Dawes, "Government and technology: User, not regulator," Journal of Public Administration Research and Theory, vol. 12, no. 4, pp. 627-631, 2002.

[23] B. Rocheleau, "Politics, accountability, and governmental information systems," G. D. Garson, Ed. Hershey, PA: Idea Group Publishing, 2003, pp. 20-52.

[24] T. Carbo and Williams, "JG Models and metrics for evaluating local electronic government systems and services," Electronic Journal of e-Government, vol. 2, no. 2, pp. 95-104, 2004.

[25] J. S. Hiller and F. Bélanger, "Privacy strategies for electronic government," $E$ government, pp. 162-198, 2001.

[26] M. M. Said, E-Government dan Pelayanan Publik dalam Reformasi Pelayanan Publik. Malang: Averroes Press, 2010.

[27] S. Haque and P. Pathrannarakul, "E-Government towards good governance: A global appraisal," Journal of E-governance, vol. 36, no. 1, pp. 25-34, 2013.

[28] M. Rehman, V. Esichaikul, and M. Kamal, "Factors influencing E-government adoption in Pakistan,"' Transforming Government: People, Process and Policy, vol. 6, no. 3, pp. 258-282, 2011.

[29] R. Kalyani, "E-Governance in India-A Conceptual Analysis," International Research Journal of Multidisciplinary Studies, vol. 4, no. 10, 2018.

[30] R. Lal, "Critique of Legal Framework Regulating E-Governance in India," RESEARCH REVIEW International Journal of Multidisciplinary, vol. 4, no. 2, pp. 391-396, 2019.

[31] N. S. Kalsi, R. Kiran, and Vaidya, "SC Enhancing e-governance initiatives for better governance in India," International Journal of Business Research Papers, vol. 5, no. 6, pp. 212-229, 2008. 
[32] N. S. Kalsi, R. Kiran, and Vaidya, "SC Changing perspectives and pragmatics of good governance and e-governance in India: a shared vision of citizens," International Journal of E-Governance, vol. 2, no. 2/3, pp. 251-271, 2009.

[33] N. S. Kalsi and R. Kiran, "E-governance success factors An analysis of e-governance initiatives of ten major states of India," International Journal of Public Sector Management, vol. 26, no. 4, pp. 320-336, 2013.

[34] L. F. Luna-Reyes and J. R. Gil-Garcia, "Using institutional theory and dynamic simulation to understand complex e-Government phenomena," Government Information Quarterly, vol. 28, no. 3, pp. 329-345, 2011.

[35] M. Johnson, “'A study of e-market adoption barriers in the local government sector," Journal of Enterprise Information Management, vol. 25, no. 6, pp. 509-536, 2012.

[36] M. Nazir, Metode Penelitian. Jakarta: Ghalia Indonesia, 2005.

[37] S. Arikunto, Penelitian Tindakan Kelas. Jakarta: Bumi Aksara, 2014.

[38] K. Krippendorff, Content analysis: An introduction to its methodology. Sage publications, 2018.

[39] R. Kriyantono, Teknik Praktis Riset Komunikasi, 6th ed. Jakarta: Kencana Prenada Media Group, 2012.

[40] A. Tat-Kei Ho, "Reinventing local governments and the e-government initiative," Public administration review, vol. 62, no. 4, pp. 434-444, 2002.

[41] D. F. Norris, P. D. Fletcher, and S. Holden, "Is your local government plugged in? Highlights of the 2000 electronic government survey," 2001.

[42] J. C. Thomas and G. Streib, "The new face of government: Citizen-initiated contacts in the era of e-government," Journal of Public Administration Research and Theory, vol. 13, no. 1, pp. 83-102, 2003.

[43] C. J. Tolbert and K. Mossberger, "The effects of e-government on trust and confidence in government," Public Administration Review, vol. 66, no. 3, pp. 354-369, 2006.

[44] "CTG - realizing_the_promise," Albany.edu. [Online]. Available: http://www. ctg. Albany. edu/publications/journals/realizing_the_promise.

[45] J. E. Fountain, "The virtual state: toward a theory of federal bureaucracy in the $21 \mathrm{st}$ century," Democracy, vol. com, pp. 133-156, 1999.

[46] J. E. Fountain, Building the virtual state: Information technology and institutional change. Brookings Institution Press, 2004. 